which had received cod-liver oil during the final stage of the experiment. The liver lesions, mainly portal fibrosis, appeared to be associated with tocopherol depletion.

We are indebted to Roche Products Ltd for the gift of Rovimix E, to Isaac Spencer \& Co. (Aberdeen) Ltd for the gift of the concentrate of vitamins $A$ and $D_{3}$ and to Mr I. A. M. Lucas and Mr A. F. C. Calder of the Department of Applied Nutrition, Rowett Research Institute for advice and assistance.

\title{
REFERENCES
}

Adamstone, F. B., Krider, J. L. \& James, M. F. (1949). Ann. N.Y. Acad. Sci. 52, 260. Blaxter, K. L. \& McGill, R. F. (1955). Vet. Rev. Annot. r, 91.

Bratzler, J. W., Loosli, J. K., Krukovsky, V. N. \& Maynard, L. A. (I950). F. Nutr. 42, 59.

Garton, G. A. \& Duncan, W. R. H. (1954). Biochem. F. 57, 120.

Hilditch, T. P. (1949). The Industrial Chemistry of the Fats and Waxes, 3rd ed., p. 47. London: Baillière, Tindall and Cox.

Hove, E. L. \& Seibold, H. R. (1955). F. Nutr. 56, I73.

Lucas, I. A. M. \& Calder, A. F. C. (1955). F. agric. Sci. 46, 307.

Nair, P. P. \& Magar, N. G. (1956). F. biol. Chem. 220, I57.

Shorland, F. B., Hansen, R. \& Hogan, K. J. (1944). Emp. F. exp. Agric. 12, I03.

Wiese, H. F. \& Hansen, A. E. (1953). F. biol. Chem. 202, 417.

Witz, W. M. \& Beeson, W. M. (195 I). F. Anim. Sci. го, г г 2.

\section{Clinical observations on obese patients during a strict reducing regimen}

\author{
By J. A. STRONG, R. PASSMORE AND FIONA J. RITCHIE \\ Departments of Medicine and Physiology, University of Edinburgh, \\ and the Western General Hospital
}

(Received 2 October 1957)

It is orthodox today to discount the value of physical exercise in treating obesity, and to rely for weight reduction on a diet supplying 1000-1200 Cal./day. The energy expenditure of a sedentary patient is about $2500 \mathrm{Cal}$./day, giving a negative energy balance of no more than $\mathrm{r}_{500 \mathrm{Cal}}$ /day. On such a regimen weight loss is slow and may therefore be discouraging. In this paper we describe a system of management suitable for some obese patients, and show that it is both possible and practicable to accelerate weight reduction by combining an active programme of physical exercise with a diet restricted to $400 \mathrm{Cal}$./day. Such a regimen can produce a negative energy balance as great as $3000 \mathrm{Cal}$./day.

It is frequently argued that during a brisk walk lasting an hour a normal subject expends about $35^{\circ} \mathrm{Cal}$, which will require the utilization of only about $40 \mathrm{~g}$ fat; and further, that such a walk may stimulate the appetite and so an excess of food will be taken. The arithmetic is correct, so far as it goes, but an obese subject expends more energy than a thin subject while walking, on account of the extra work needed to move 
the mass of excess tissue. Nevertheless, the fat removed in one hour's walk weighs little, and might appear to be negligible. However, if the walk is extended to $3 \mathrm{~h}$ daily and such a regimen followed for a month, the fat utilized during the walking will be ninety times this amount, or $3.6 \mathrm{~kg}$-by no means negligible. Further, although a brief period of unaccustomed exercise in a sedentary person may well promote appetite, regular exercise in obese patients is not necessarily associated with any increase of appetite, as we shall show.

Severe dietary restrictions in obesity are sometimes stated to be contra-indicated because ketosis may develop. Folin \& Denis (I9I5) found that severe acidosis did not necessarily accompany complete starvation in obese patients. Kekwick \& Pawan (1953) and Warming-Larsen (1954) have shown that most fat persons develop little or no ketosis under dietary restrictions which in normal people would involve a severe ketosis. We have confirmed this finding and shown further that, in an obese patient, even if a moderate ketosis does follow dietary restriction, it may in no way upset his sense of well-being or interfere with a programme of physical exercise.

A preliminary account of this work has already been given (Strong, Passmore \& Ritchie, 1957).

\section{EXPERIMENTAL}

\section{The regimen}

During the period of study (40-45 days) the patients were admitted to a general medical hospital ward.

Diet. The diet for the most part contained about $400 \mathrm{Cal}$./day, provided by about $40 \mathrm{~g}$ carbohydrate, $25 \mathrm{~g}$ protein and $15 \mathrm{~g}$ fat. The pattern of this diet is shown in Table 1 . Two patients were fed for $\mathrm{I}_{5}$ days on a purely artificial diet of $80 \mathrm{~g}$ of Complan (a comprehensive food prepared by Glaxo Laboratories Ltd), providing $25 \mathrm{~g}$ protein and $360 \mathrm{Cal}$. daily. The powder was found most palatable when made up

Table 1. Pattern of 400 Cal. diet

\begin{tabular}{|c|c|c|c|c|}
\hline & $\begin{array}{l}\text { Carbohydrate } \\
\text { (g) }\end{array}$ & $\begin{array}{l}\text { Protein } \\
\quad(g)\end{array}$ & $\begin{array}{l}\text { Fat } \\
(\mathrm{g})\end{array}$ & $\begin{array}{l}\text { Calories } \\
\text { (Cal.) }\end{array}$ \\
\hline Milk (daily allowance roo g) & 5 & 3 & 4 & 68 \\
\hline $\begin{array}{l}\text { Breakfast, } 8 \text { a.m.: fresh or stewed fruit (con- } \\
\text { taining Io or } 15 \% \text { carbohydrate) }\end{array}$ & 10 & - & 一 & 40 \\
\hline Tea & - & 一 & 一 & - \\
\hline Snack, i 1 a.m.: tea or coffee & - & - & - & - \\
\hline $\begin{array}{l}\text { Lunch, I.o p.m.: lean meat or fish (small } \\
\text { portion) }\end{array}$ & - & Io & 5 & 85 \\
\hline Vegetables (containing 3 or $6 \%$ carbohydrate) & e) & $\mathbf{I}$ & - & 20 \\
\hline Fresh or stewed fruit & Io & - & - & 40 \\
\hline $\begin{array}{l}\text { Tea, } 4 \text { p.m.: fresh fruit or Energen* rolls or } \\
\text { water biscuits }\end{array}$ & Io & - & - & 40 \\
\hline Supper, 6.30 p.m.: lean meat, fish or egg & $\ldots$ & 10 & 5 & 85 \\
\hline Salad (containing $3 \%$ carbohydrate) & 2 & $\mathbf{I}$ & - & 12 \\
\hline Tea & - & - & - & - \\
\hline Total & $4 \mathrm{I}$ & 25 & 14 & 390 \\
\hline
\end{tabular}

* A wheat-gluten bread (Energen Foods Co. Ltd, London). 
with water, flavoured with coffee, vanilla or the like, and taken as a cold drink at intervals during the day.

On several occasions the protein content of the diet, and to a smaller extent the calorie value, were raised in order to study the effect of an increased nitrogen intake on the nitrogen balance (Passmore, Strong \& Ritchie, 1958). This increase was effected by giving an egg instead of fruit at breakfast, and increasing the portions of lean meat or fish at the midday and evening meals.

Diets providing $1000 \mathrm{Cal}$, $85 \%$ derived from carbohydrate, were given to two patients for short periods in order to study the effect on water losses (Passmore, Strong \& Ritchie, in preparation). This diet, containing about $210 \mathrm{~g}$ carbohydrate, $22 \mathrm{~g}$ protein and $8 \mathrm{~g}$ fat, consisted of white bread, jam, fruit, vegetables (including potato), with a small quantity of milk.

Calculations of the content of the proximate principles and the caloric value of each day's diet were made from McCance \& Widdowson's (1946) tables.

Exercise. Patients were encouraged to walk outside for $3-4$ h each day, conditions permitting. On wet days a long corridor inside the hospital was used. Each patient kept a diary in which the exact time spent at exercise was recorded. The keeping of this record by the patients impresses on their minds the importance of the exercise and is an essential part of the therapeutic regimen. In addition, for research purposes, the patients kept a record of all their other daily activities. This is a necessary step in the estimation of the total energy expenditure, recorded in Table 2, but described by Passmore et al. (1958).

\section{Description of the patients}

The patients had all been referred to a Dietetic Department for a suitable weightreducing diet. They were chosen for study on account of their (I) desire to lose weight, (2) physical fitness to walk, (3) interest and intelligence, when this was considered sufficient for them to co-operate in keeping simple records of their activities, and (4) social and financial circumstances which allowed them to leave their homes and usual occupations for about 2 months.

Patient I. Mr I., age 32 , married, two children, a civilian clerk in the Territorial

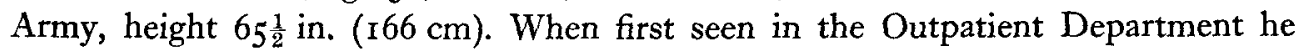
weighed $238 \mathrm{lb}$ (108 kg), and was complaining of lumbar pain, for which no anatomical cause was subsequently found. He was an active man who had practised as an amateur weight lifter; he enjoyed Scottish country dancing, and spent part of his spare time serving with the Royal Observer Corps. Physical examination showed no disability other than excessive weight.

Patient 2. Mrs R., age 40, two children, housewife, height $64 \frac{1}{4}$ in. ( $163 \mathrm{~cm}$ ). When first seen she weighed $304 \mathrm{lb}$. (138 kg). She was the daughter of a doctor and had made sporadic attempts to reduce her weight; at one time she had been treated with thyroid-gland extract. Mentally and physically she was animated and, in spite of her weight, was very active. The menstrual history was normal. Physical examination showed no abnormality other than obesity.

Patient 3. Mrs L., age 39, two children, housewife, height $68 \frac{1}{4} \mathrm{in.}(173 \mathrm{~cm}$ ). On 
admission she weighed $36 \mathrm{r} \mathrm{lb}$. (164 kg). The menstrual history was normal. She claimed that in spite of her weight she did all her own housework and shopping, but was sometimes breathless. Physical examination showed no abnormality apart from gross obesity.

Patient 4. Miss McN., age 24, cashier, height $6 \mathrm{I}_{2} \frac{1}{2}$ in. $\left(15^{6} \mathrm{~cm}\right)$. When first seen in the Outpatient Department, she weighed $239 \mathrm{lb}$. (ro9 kg). Two years previously she had succeeded in reducing her weight from 224 to $168 \mathrm{lb}$. but, as soon as she ceased deliberately restraining her appetite, her weight increased rapidly. She had tried taking amphetamine, which only made her ill-tempered. The menstrual history was normal. Physical examination showed obesity; she had a high degree of myopia.

Patient 5. Miss B., age 32, schoolteacher, height 62 in. ( $157 \mathrm{~cm})$. When first admitted to hospital she weighed $240 \mathrm{lb}$. (109 kg). She had been obese since childhood, and had never menstruated. She had rudimentary development of the breasts, and the uterus on palpation was considered to be smaller than normal. Physical examination showed no other abnormalities. In particular there was no clinical evidence of hypopituitarism, or any of the other signs of Turner's syndrome. She had previously been treated with thyroid and desiccated pituitary snuff, which she took sporadically without evident effect. On two occasions tests of thyroid function with radio-iodine indicated hypothyroidism, but there was no clinical confirmation of it during the 6 months she was under observation. The plasma cholesterol concentration (254 and $297 \mathrm{mg} / \mathrm{r} 00 \mathrm{ml}$. on two occasions) remained within normal range. These findings might be explained by the surreptitious use of thyroid, but we are satisfied that she was not taking the drug at that time. In earlier years she had succeeded in reducing weight satisfactorily, but her weight again increased as soon as she returned to an ordinary diet.

Patient 6. Miss M., age 25, clerk, height $64 \frac{1}{2}$ in. $\left(\mathrm{r}_{4} \mathrm{~cm}\right)$. On admission she weighed $263 \mathrm{lb}$. ( $119 \mathrm{~kg}$ ). She had been overweight from the age of $\mathrm{I}_{4}$ and had made sporadic attempts on her own initiative and without supervision to reduce her weight by dieting. For the 2 years before admission she had been under the care of the Tuberculosis Authorities, who had treated her successfully for primary pulmonary tuberculosis. During this time she had only gained $4 \mathrm{lb}$. in weight. The menstrual history was normal. No abnormality was found on physical examination other than gross obesity and genu valgum deformity.

Patient 7. $\mathrm{Mr} \mathrm{W}$., age $3 \mathrm{I}$, married with one child, male nurse. Height 70 in. $(\mathrm{I} 78 \mathrm{~cm}$ ). Weight on admission $289 \mathrm{lb}$. ( $13 \mathrm{I} \mathrm{kg})$. He had been overweight from the age of 7 , after an attack of scarlet fever. At the age of 14 his obesity was treated by dieting, with some temporary success. Physical examination showed no abnormality other than obesity and some varicose veins.

\section{RESULTS}

Loss of weight. Table 2 shows the total loss of weight in each patient during 6 weeks. It also shows the mean daily negative calorie balance on the regimen. The weight losses correspond to a weekly mean loss of from $4 \cdot 7$ to $6 \cdot 0 \mathrm{lb} .\left(2 \cdot 14^{-2} \cdot 73 \mathrm{~kg}\right)$. This is 
a more rapid rate of reduction than is possible on more orthodox regimens. The patients appreciated the rapid loss of weight, which encouraged them to persevere.

Table 2 also shows the mean daily energy balances, which ranged from $-245^{\circ}$ to $-3100 \mathrm{Cal}$./day, and account for the rapid losses of weight achieved. Such energy debits can only be established when the patient is tolerably fit physically, and is determined to persist in making the effort. Although surprised at first by the amount of exercise expected of them, most were more surprised at the ease with which they were soon able to maintain the quota of exercise required.

Table 2. Energy balance and weight loss of seven patients during 42 days on the reducing regimen

Miss M. Mr W.

$\begin{array}{lrrrrrrr} & \text { Mr I. } & \text { Mrs R. } & \text { Mrs L. Miss McN. Miss B. (45 days) (40 days) } \\ \text { Weight: } & & & & & & & \\ \quad \text { Initial (kg) } & 104 \cdot 4 & 138 \cdot 9 & 163 \cdot 8 & 106 \cdot 0 & 107 \cdot 6 & \mathbf{1} 18 \cdot 5 & 131 \cdot 3 \\ \text { Final (kg) } & 91 \cdot 0 & 122 \cdot 6 & 147 \cdot 8 & 91 \cdot 0 & 94 \cdot 6 & 101 \cdot 2 & 115 \cdot 3 \\ \text { Loss (kg) } & 13 \cdot 4 & 16 \cdot 3 & 16 \cdot 0 & 15 \cdot 0 & 13 \cdot 0 & 17 \cdot 3 & 16 \cdot 0 \\ \text { Energy: } & & & & & & & \\ \text { Mean daily expenditure (Cal.) } & 3000 & 3360 & 3060 & 3200 & 2850 & 3260 & 3590 \\ \quad \text { Mean daily intake (Cal.) } & 550 & 430 & 410 & 460 & 370 & 460 & 490 \\ \text { Mean daily balance (Cal.) } & -2450 & -2930 & -2650 & -2740 & -2480 & -2800 & -3100\end{array}$

General health. Apart from minor respiratory infections and orthopaedic complaints the patients remained physically well and all stated that they felt much fitter when on the regimen. Psychological disturbances are, of course, common in the obese and have indeed been held responsible for the development of fatness. Some of the patients had occasional emotional outbursts and episodes of depression, but these were not sufficiently severe to lead to any change in the treatment. For the most part they remained cheerful and co-operative.

Complaints of constipation which might have been expected on such a meagre diet were very seldom made. The bulk of the food was kept as high as possible with the small calorie intake and thus, although the average faecal output was naturally small, little difficulty was experienced in defaecation.

Appetite. We were surprised that the subjects complained very little of hunger. Although all were frequently outside the hospital and its discipline when on their walks, we are reasonably sure that they rarely took unauthorized food. There was convincing internal evidence from the daily weighings and daily urine analyses to support their statements that they had adhered strictly to the diets. Mrs R. had two hearty meals away from hospital at a time when she was troubled by emotional disturbance of domestic origin. On the other hand, Miss McN., Miss B. and Mr W. frequently did not eat the whole of the diet provided and returned portions to the kitchen.

Hunger may not be severe when the diet is greatly restricted. Several professional fasting men were much studied by physiologists over the period I890-1910. Van Noorden (1907) and Benedict (1915) reviewed this literature, but seldom mention and never seriously discuss hunger and appetite. It would appear that the fasts, in which 
no food at all was eaten, were not usually associated with excessive or frequent complaints of hunger. Professional fasters can hardly be described as psychologically normal men, and professional pride may have restricted their complaints and grumbles. To some extent the free acceptance of the regimen by our patients was in the nature of a self-imposed discipline. Unwillingness to admit defeat may have contributed to their ability to persist and also reduced complaints of hunger.

In partial starvation, in contrast to complete fasting, the sensation of hunger is almost constantly present. Thus, in the Nazi concentration camps, 'the thoughts and conversation of most prisoners mainly centred on food' (Helweg-Larsen, Hoffmeyer, Kieler, Thaysen, Thaysen, Thygesen \& Wulff, I952). In German prisoner-of-war camps, 'a growing feeling of hunger followed and gradually increased in intensity until, after about three weeks, the whole thought of the prisoner-of-war was concentrated on his food' (Leyton, I946). Similarly, in semi-starvation, as studied in the Minnesota experiment, 'the persistent clamor of hunger distracted the subjects when they attempted to continue their cultural interests, manual activities, and studies' (Keys, Brožek, Henschel, Mickelsen \& Taylor, 1950).

Observations on our subjects are consistent with the hypothesis that the sensation of hunger, which is such a constant feature of semi-starvation, fades when the negative caloric balance is high and the subject approaches a fasting condition. The complicated psychological factors involved make the testing of such an hypothesis difficult, nor have we any adequate physiological explanation for the virtual absence of hunger and meagre appetite in our patients. There is, however, no doubt that excessive hunger does not constitute a bar to the strict regimen which was imposed on these patients.

Ketosis. Urines were tested daily by the Rothera test for ketone bodies. Four of the patients never developed more than slight ketosis, the results of urinary tests being usually reported as 'trace' or ' +'. Three (Miss McN., Miss M. and Mr W.) developed a moderate ketosis and the urine tests were mostly recorded as ' ++ ' or ' +++ '. It did not appear to affect their health in any way and for most of the 6 weeks they felt very well.

Throughout the period in hospital the patients were deriving about $90 \%$ of their energy from the combustion of fat. Their respiratory quotients, both at rest and when walking, were usually well below 0.76 (Table 3 ). This appears to be a critical level in normal persons, below which ketosis usually develops (Courtice \& Douglas, 1936). We have found that in normal subjects when the R.Q. falls below this level (as when resting after a 10-mile walk undertaken in the postabsorptive state) the Rothera reaction is usually strongly positive. In obese subjects factors other than the relative proportion of fat in the metabolic mixtures (as indicated by the value of the R.Q.) must influence the presence or absence of ketosis. Lyon, Dunlop \& Stewart (1932) also found that the R.Q. in obese patients was often very low and was not associated with ketosis. This is evidence of an important metabolic difference between obese and normal people. We cannot explain the difference in biochemical terms. The conditions under which ketosis arises are not yet fully understood. The present position has been well reviewed by Campbell \& Best (1956). 
On the practical side there can be no doubt that the presence of ketosis need not prevent the use of a low-calorie and high-exercise regimen in the treatment of many obese patients.

Table 3. Mean respiratory quotients of seven patients during various activities

\begin{tabular}{llll} 
& \multicolumn{1}{c}{ Lying } & Sitting & Walking \\
Mr I. & $0.74(8)$ & $0.78(7)$ & $0.70(10)$ \\
Mrs R. & $0.72(13)$ & $0.71(10)$ & $0.72(8)$ \\
Mrs L. & $0.68(7)$ & $0.71(9)$ & $0.64(6)$ \\
Miss McN. & $0.67(14)$ & $0.70(14)$ & $0.68(18)$ \\
Miss B. & $0.72(10)$ & $0.70(10)$ & $0.70(8)$ \\
Miss M. & $0.70(15)$ & $0.70(14)$ & $0.71(20)$ \\
Mr W. & $0.71(10)$ & $0.74(18)$ & $0.77(15)$
\end{tabular}

Number of observations in parentheses.

\section{DISCUSSION}

Patients with obesity frequently claim that they have often attempted to reduce weight by dieting, but that it is ineffective. The treatment of obesity is still in many ways an exercise of will power, both on the part of the patient and of the physician. Even among patients who understand and accept the necessity for reducing weight, the effort required to adhere to any form of dietary restriction is beyond the capacity of many. The successful treatment of these patients depends, in the first place, on a clear demonstration that the treatment is practicable and effective, and secondly on the capacity of the individual to adopt and maintain unaccustomed eating habits.

Admission of these patients to hospital for a period confers several valuable advantages. The change of environment makes the change in diet more acceptable; habits of so fundamental a nature as eating require a vigorous stimulus and strict adherence to a new manner of living if they are to be radically altered, and if this alteration is to be sustained. Admission to hospital impresses on the patient that obesity is to be regarded as a serious disease, and while in hospital these new habits can be initiated. For many people even the kindliest discipline of hospital routine is helpful.

From every point of view perhaps the most serious potential disadvantage of inpatient treatment might be a wrong emphasis, in that the responsibility for the treatment of the condition may tend to be shifted from the patient, where it properly belongs, to the hospital and its staff. This tendency must be constantly opposed, and every effort made to ensure that the management of the condition becomes entirely the care of the patient before leaving.

The rapid rate of weight loss achieved on this regimen enhances the value of the time spent in hospital. The substantial losses are encouraging, the value of physical exercise is established, and when the patients ultimately leave hospital on a less rigidly restricted diet, they do so with increased self-respect, a sense of real achievement, and a determination to persist, none of which are constantly obtained on the more conventional forms of out-patient management.

Ultimate success in reaching and maintaining a normal weight is far from usual in obesity, and it is too soon to draw any conclusions about these seven patients. Each 
continued to lose weight while under outpatient supervision, but two defaulted after some months. The majority of patients of this type still appear to depend on supervision for the support required to maintain progress.

\section{SUMMARY}

I. The treatment of obesity by a reducing regimen combining a $400 \mathrm{Cal}$. diet with regular exercise (up to 4 hours' walking a day) is described.

2. Observations were made in hospital on seven patients, each of whom lost $13^{-16} \mathrm{~kg}$ in 6 weeks. There were negative energy balances of as much as $3^{100} \mathrm{Cal}$. daily.

3. The patients remained in good health, and hunger was not excessive. Persistent moderate ketosis developed in three patients, but did not interfere in any way with their sense of well-being or activities.

We are indebted to Miss J. Halley, Chief Dietitian, for much help, and to Sisters MacDonald and MacLeod for their careful supervision of these patients. We wish to thank the Medical Research Council for a personal grant to one of us (F.J.R.) and also for an expense grant.

\section{REFERENCES}

Benedict, F. G. (1915). Publ. Carneg. Instn, no. 203.

Campbell, J. \& Best, C. H. (1956). Metabolism, 5, 95.

Courtice, F. C. \& Douglas, C. G. (1936). Proc. roy. Soc. B, II9, 38 r.

Folin, O. \& Denis, W. (I9r5). F. biol. Chem. 21, 183.

Helweg-Larsen, P., Hoffmeyer, H., Kieler, J., Thaysen, E. H., Thaysen, J. H., Thygesen, P. \& Wulff, M. H. (1952). Acta med. scand. 144, suppl. p. 274.

Kekwick, A. \& Pawan, G. L. S. (1953). Arch. Middx Hosp. 3, 139.

Keys, A., Brožek, J., Henschel, A. F., Mickelsen, O. \& Taylor, H. L. (1950). The Biology of Human Starvation, p. 833. Minnesota: University Press.

Leyton, G. B. (1946). Lancet, 251, 73.

Lyon, D. M., Dunlop, D. M. \& Stewart, C. P. (1932). Biochem. F. 26, I 107.

McCance, R. A. \& Widdowson, E. M. (1946). Spec. Rep. Ser. med. Res. Coun., Lond., no. 235, and ed, Passmore, R., Strong, J. A. \& Ritchie, F. J. (1958), Brit. F. Nutr. r2, I 13.

Strong, J. A., Passmore, R. \& Ritchie, F. J. (1957). F. Endocrinol. 15, xxiv.

Van Noorden, K. (1907). Metabolism and Practical Medicine, Vol. 2, Ch. I. London: William Heinemann.

Warming-Larsen, A. (1954). Acta med. scand. r5o, 47. 